\title{
MEHHANISTLIKUST JA MENTALISTLIKUST ANDEKUSEST
}

2008. aastal esitasid Kanada bioloog Bernard Crespi ja Londoni sotsioloog Christopher Badcock teooria, millega saab evolutsiooniliselt seletada nii vaimuhaiguste pärilikkust kui ka inimese intelligentsuse erinevaid vorme. ${ }^{1}$ Inimese embrüo saab teatavasti alguse viljastatud munarakust, uus organism pärib harilikult kaks genoomi koopiat ehk ühe alleeli isalt ja teise emalt. Mõjuandva „,iseka geeni“ teooria järgi on erinevatest organismidest pärinevatel geenidel erinevad käitumise strateegiad. Isa ja ema geenide „huvide“ lahknemisest tuleneb geneetiline konflikt, mille käigus mõlemad üritavad loote arengut suunata endale soodsas suunas. Isa geenide huvides on kasvatada laps võimalikult suureks, kasutades selleks ema ressursse. Ema geenid reguleerivad embrüo kasvu mõõdukamaks. Seda konfliktset mehhanismi nimetatakse imprinting ja vastavat ajuteooriat Imprinted Brain Theory. ${ }^{2}$ Bostoni bioloogi David Haigi töödest nähtub, et rasedus on palju muudki kui harmooniline ema ja lapse koostöö. ${ }^{3}$ Rasedus on ohtlik lahinguväli isa ja ema geenide vahel, milles mõlemad pooled üritavad embrüot ehitades teise poole mõju epigeneetiliste mehhanismide kaudu välja lülitada. Sugupoolte vaheline „võitlus“ algab juba emaüsas. Seetõttu on embrüo

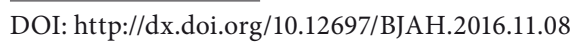

1 Bernard J. Crespi, Christopher Badcock, „Psychosis and Autism as Diametrical Disorders of the Social Brain“, Behavioural and Brain Sciences, 31 (2008), 241-320.

2 Christopher Badcock, The Imprinted Brain: How Genes Set the Balance Between Autism and Psychosis (London, Philadelphia: Jessica Kingsley Publishers, 2009).

3 David Haig, „Genetic Conflicts in Human Pregnancy“, Quarterly Review of Biology, 68 (4) (1993), 495-532. 
areng läbi aegade olnud riskantne seisund nii emale kui lapsele, mille suurt ohtu tervisele suudab alles moodne meditsiin kahandada.

Inimese aju on juba sündides teataval määral „valmis“ ja kultuur ning kasvatus suudavad seda ainult mõningal ulatusel mõjutada. Crespi ja Badcocki teooria järgi eelistavad isa ja ema geenid isekalt ajusid ehitades arendada erinevaid intelligentsuse vorme. Isa geenid eelistavad mehhanistlikku intellekti ehk arendada mõtlemist asjade üle. Ema geenid seevastu toetavad n-ö mentalistlikku intellekti, mis annab inimesele sotsiaalsed võimed suhelda, kaasinimesi mõista ja viisakalt käituda. Geneetilise konflikti tulemusena enamasti kumbki pool suurt võitu ei saavuta, seetõttu on inimesel harilikult olemas mõlemad võimed mõelda mõistlikult nii asjadest kui kaasinimestest. Juhul kui isa geenid saavutavad emapoolseid alleele välja lülitades suurema võidu, tekib risk autismile. Kui aga ema geenid osutuvad n-ö edukamaks, võib tekkida psühhootiline haigus (nt skisofreenia). Autismi ja psühhoosi vaadeldakse siin kui kahte tüüpi intelligentsuse patoloogilisi vorme. Kuna iga inimene pärineb oma isast ja emast, on inimese ajus kaks kognitiivse süsteemi, mis tähendab, et aju töötab kahefaasiliselt. Teisisõnu, kognitsioon ei ole unitaarne, vaid dualistliku loomuga. Viimati mainitud tõsiasja võtavad tõsiselt väga paljud ajuteadlaste ja kognitivistide koolkonnad, ka need, kes otseselt ei tegele nähtusega imprinting. ${ }^{4}$

Käsitlus inimese aju kahetisest loomusest ennustab ka seda, et inimene võib oma mõtlemises ja maailmatajus olla "tark" kahel erineval viisil - autistlikul ja psühhootilisel. Sõna ",teadja“ või „tark“ kohta kasutatakse sageli prantsuskeelset terminit savant. Autismispektris olev savant on sageli erakordselt hea mäluga, kelle aju talletab informatsiooni modulaarsel viisil ehk iseenesest ja ilma pingutamata. Iiri psühhiaater Michael Fitzgerald kasutab hästi funktsioneerivate autistlike savant' ide seisundi kirjeldamiseks terminit „Asperger savantism“. ${ }^{5}$ Palju teadlasi ja loomeinimesi kuulub sellesse kategooriasse, nii näiteks leidub Eestis analüüse Uku Masingu ja Heimar Ilvese kohta. ${ }^{6}$

4 Vaata näiteks: Anthony I. Jack, „A Scientific Case for Conceptual Dualism: The Problem of Consciousness and the Opposing Domains Hypothesis“, Oxford Studies in Experimental Philosophy, Consciousness and the Opposing Domains Hypothesis", Oxford Studies in Experimental Philosophy
vol. 1 (Oxford: Oxford University Press, 2014), 173-207.

作 on Autism Spectrum Disorders, ed. by Mohammad-Reza Mohammadi (InTech, 2011), 213-224.

6 Amar Annus, „Diagnoosita savant: uurimus Uku Masingust ja autismispektrist", Akadeemia 1-2 (2015), 113-152, 240-264, Amar Annus, , Religioon ja savantism - mida uskus Heimar lives? 15, http://kjt.ee/2015/06/religioon-ja-savantism-mida-uskus-heimar-ilve (vaadatud 02.11.2016).
Crespi ja Badcocki teooria viitab, et peale mehhanistlike geeniuste on olemas ka mentalistlikud geeniused, keda võib ära tunda nende täiusliku suhtlemisoskuse järgi. Just nagu autism ja psühhoos on selle teooria järgi diameetriliselt vastandlikud meelehaigused, on ka savantism nähtusena sümmeetriline. ${ }^{7}$ Kui autistlik savant võib mõjuda inimesena kummaliselt, siis psühhootiline savant paistab teistele enamasti täiesti tavalise ja normaalsena. ${ }^{8}$ Siiski on ta mentalistlik geenius ehk teiste sõnadega psühhootiline savant, kes naudib inimeste hulgas viibimist ja tunneb ennast seal mugavalt. Need inimesed on erakordsete mentaalsete võimetega isikud, eelkõige osavad suhtekorraldajad, kellel on suurepärane ettekujutus erinevate inimeste ja gruppide vaimsetest ootustest, mida ja kuidas rääkida teatavatele kuulajatele isesugustes olukordades. Kuidas võita sõpru ja mõjutada inimesi on võime, mis mentalistlike geeniuste juures on eriti hästi arenenud. Sellest tulenevalt leidub selliseid inimesi märkimisväärselt palju poliitilistes ringkondades.

Termin „psühhootiline savant" on oma olemuselt kirjeldav ja neutraalne. See ei tähenda koheselt manipulaatorit ja inimeste ärakasutajat Macchiavelli mõttes. Viimase kohta kasutatakse rohkem mõistet ",sotsiopaat“ või „psühhopaat“. Niinimetatud psühhootiline savant võib olla ka tavaline inimene tänavalt, nt hinnatud ja armastatud poemüüja või pedagoog. Sellised mentalistlikud geeniused võivad olla tegevad näiteks reklaaminduses, müügitöös, imagoloogias, psühholoogia ja hingehoiu erinevates valdkondades, avalike suhete osakondades, suhtekorralduses, sotsiaalteadustes, poliitiliste ja usuliste liidritena. Laiemalt võttes võib paljusid mentalistlikult andekaid inimesi liigitada skisotüüpilisteks, kelle hulgas leidub suurel hulgal loomingulisi isikuid. ${ }^{9}$

Teatud omapärade tõttu tuleks psühhootiliste savant'idega suheldes säilitada valvsus ning ei tohiks sattuda nende veenmisoskuse ja sarmi tõttu neist pimedasse vaimustusse. Suurepärase kontekstitaju tõttu on neil loomupärane oskus vastavalt olukorrale musta valgeks ja valget mustaks rääkida. Erinevalt autistlikust isikust ei valmista psühhootilisele savant 'ile valetamine ega tõe varjamine mingit raskust. Kui sellele lisanduvad veel ahnus, võimuiha või tahe domineerida, võib psüh-

7 Christopher Badcock, ,, The Symmetry of Savantism“, Psychology Today, 21.08.2009,

https://www.psychologytoday.com/blog/the-imprinted-brain/200908/the-symmetry-savantism (vaadatud 02.11.2016)

Chidem.

Wor Gordin Claridge, „Schizotypy - Do Not Worry, It Is Not All Worrisome“ Schizophrenia Bulletin, 41 (2015), 436-443. 
hootilise savant'i näol olla tegemist tõelise monstrumiga. Evolutsioon on igale inimesele, isegi kui tahes geniaalsele seadnud omad piirid. Psühhootilisele savant ile on loodus andnud erakordselt hea intuitiivse inimesetundmise, kuid asjade maailma, füüsikat ja loodust mõistab ta parimal juhul keskpäraselt. Siin leidub analoogia autistliku savant iga, kellel võivad olla erakordsed oskused näiteks muusikas, matemaatikas, keelte tundmises jms, kuid sotsiaalses mõttes võib inimene olla keskpärane, sageli ka põikpäine ning seltskondlikus mõttes igav või frustreerivalt ärritav. Kuna psühhootiline savant tunneb väga suurt tõmmet teiste inimeste poole, siis on ta ka kergelt valmis andma hinnanguid teiste inimeste käitumisele. Kui see on näiteks tema karjääri jaoks oluline, suudab ta suhtekorraldusliku osavusega oma konkurente kõrvaldada. Psühhootiliste savant ide loomupäraste oskuste hulka kuuluvad ka kampaaniate ja infosõdade korraldamine ning juhtimine. Halvemal juhul ei huvita psühhootilist savant i ïldse see, kuidas asjad päriselt võiksid olla, vaid inimeste mõjutamine kas või lihtsalt selleks, et neid omavahel tülli ajada. Psühhootiliste meediakampaaniate musternäide võiks olla kaasaegse Venemaa infosõjad. Pealiskaudse meediakampaania jaoks on tarvis leida mõni vaenlase kuju ning süüdistada seda meelevaldselt kõiges, mis pähe tuleb - naming, blaming and shaming.

Kui palju võib leiduda üldises rahvastikus selliste võimetega inimesi, nn psühhootilisi savant'e? Kuigi selliseid uurimusi tehtud veel ei ole, on mentalistlikult andekaid inimesi kindlasti vähemalt $1 \%$ kogu elanikkonnast. Proportsionaalselt kordades rohkem leidub psühhootilisi savant'e poliitikas ja parteide tagatubades. Kuigi sellistel inimestel on ühiskonnas kindel koht ja nad on vajalikud, ei tohiks neid valida ametikohtadele, mis nõuavad head tehnilist taipu, asjade korraldamist ja teaduslikku kompetentsi. Psühhootilise savant'i suurim andekus seisneb inimestega ümberkäimises ja nende veenmises, seejuures jättes endast väga head muljet. See seletab ka, miks poliitikas sageli domineerivad rahvale sümpaatsed, kuid vaimsetelt võimetelt keskpärased inimesed. Eetiline vastutus ühiskonnas toimuva eest peab põhinema tasakaalul kompetentse asjadest mõtlemise ja inimestega arvestamise vahel. Sellise dünaamilise tasakaalu saavutamise nimel peaksid poliitilised juhid aktiivselt töötama kahest perspektiivist - mehhanistlikust ja mentalistlikust - lähtudes, ning püüdma neid kognitsiooni stiile mitte kohaldada väärale valdkonnale. Selline menetlus annab võimaluse tõeliselt eetilise juhtimisstiili esile kerkimiseks. ${ }^{10}$

Siia võib lisada ühe konkreetse näite tasakaalutust arengust, mis viib kahetsusväärsete tulemusteni. Christopher Badcock oma blogis ajakirja juures Psychology Today kirjutab nõukogude bioloog Trofim Lõssenkost (1898-1976) kui psühhootilisest savant 'ist. ${ }^{11}$ Lõssenko oli teadlasena keskpärane, tema saavutus bioloogina oli nt Mendeli geneetika nimetamine „kapitalistlikuks“ ja geeni olemasolu eitamine. Samuti oli tal ebapädevaid teaduslikke ideid, kuidas „õpetada“ taimi elama neile ebasobivas kliimas. Seevastu ühel alal oli Lõssenko suurepärane - ta oskas lugeda ja ära arvata Stalini tujusid ja suhtumisi ning oivaliselt laveerida võimuringkondades. Tema karjäär nõukogude teadlasena oli hiilgav, oma vaadete vastastest teadlaskonnas ta vabanes. Lõssenko sai suurel hulgal aumedaleid, kuigi tema tööde teaduslik sisu on tänaseks unustatud. See on hoiatav näide mentaalset laadi osavusest, mis võib omas ajas inimestele meeldida, kuid pikemas perspektiivis saada kogu ühiskonnale katastroofilist laadi teguriks.

Diameetrilist mudelit aluseks võttes võib seega rääkida kahte tüüpi andekusest, mehhanistlikust ja mentalistlikust, millest üks sageli välistab teise. Kui aga panna loovalt koostööd tegema autistlik ja psühhootiline savant, siis sellest võiks potentsiaalselt tekkida geniaalsus. Selle vaate läbi on geniaalsuseks vaja vähemalt kaht inimest. Kui geenius juhtub olema üks inimene, peaks ta esindama mõlemat tüüpi talenti korraga, mida loodus võimaldab ainult erandjuhtudel. Sellised inimesed esinevad küll kirjanduses, nt kriminaalromaanides, kus kuritegude geniaalsed lahendajad suudavad täpselt analüüsida nii asjaolusid kui ka asjasse segatud inimesi. Badcock arvab, et kriminaalromaanide suur populaarsus rajaneb suuresti lummuses ebainimlikult täiuslike kangelaste suhtes. ${ }^{12}$ Pole siiski välistatud, et nn „,tõeline geenius“ siiski eksisteerib, kui ühes inimeses leidub nii mehhanistliku kui mentalistlikku andekust keskmisest rohkem, kliiniliselt öeldes autism ja skisofreenia ühekorraga. Hea näide siin on matemaatik ja mänguteoreetik, Nobeli preemia laureaat John Forbes Nash (1928-2015), kellel arvatavasti olid mõlemad

10 Kylie C. Rochford, Anthony I. Jack, Richard E. Boyatzis, Shannon E. French, „Ethical Leadership as a Balance Between Opposing Neural Networks", Journal of Business Ethics (2016), 1-16. 11 Christopher Badcock, ,,The Lasting Lesson of Lysenko“, Psychology Today, 11.01.2014, https://www.psychologytoday.com/blog/the-imprinted-brain/201401/the-lasting-lesson-lysenko 12 Badcock, The Imprinted Brain: How Genes Set the Balance Between Autism and Psychosis, 196-199. 
meelehaigused. ${ }^{13}$ Tema eluloo järgi tehtud film A Beautiful Mind (2001) võimaldab kunstilisse vormi valatud lähivaatlust geniaalsusele ja muudele sellega seotud aspektidele.

Amar Annus: Tho Types of Talents - Mentalistic and Mechanistic

Keywords: Imprinted Brain Theory; autism; psychosis; MenTALISM; EPIGENETICS

SUMMARY:

Recent advances in cognitive neurosciences compellingly suggest that the human brain does not have a single cognitive system, but two parallel cognitive systems. These two systems normally blend more or less perfectly in the human mind. Only the failure of one reveals the existence of the other in a way that would otherwise be difficult to discern. ${ }^{14}$ This research has established that "human beings have evolved two parallel ways of thinking. One, which you might call people-thinking, mentalistic cognition - or more simply mentalism - is wholly concerned with understanding human beings, their minds, motives, and emotions; the other, which by contrast you could call things-thinking or mechanistic cognition, is concerned with understanding and interacting with the physical, non-human universe of inert objects “. ${ }^{\text {" }}$

In other words, the social brain works entirely differently from mechanistic thinking, using altogether different neural pathways. The current view in the cognitive sciences supports the dual process theory that distinguishes between analytical and intuitive styles of information processing. These two styles - analytical and intuitive - broadly correspond to mechanistic and mentalistic cognition modes. Analytical processing involves abstract, rule-based, logical and deliberate thought, whereas the intuitive style is implicit and contextualized, taking advan-

13 Fitzgerald, „Creativity, Psychosis, Autism and the Social Brain“.

4 Badcock, The Imprinted Brain: How Genes Set the Balance Between Autism and Psychosis, 11. 15 Ibidem, 15. tage of associations. ${ }^{16}$ These two styles can be viewed as the polar ends of a single continuum, best understood as processing modes which individuals move in and out of in a continuous manner, depending on the situational dynamics. ${ }^{17}$ However, these two cognitive styles can become the preferences for cognition and learning if one prevails over the other.

The general discussions on higher cognitive processes usually do not cite evidence from the studies of clinical population groups. In my view, such discussions are necessary. In a clinical condition, the cognitive preference inevitably becomes a bias, even a strong bias for thinking and behaviour. The clinical conditions have genetic and epigenetic causes, even if these are only partly known. According to the Extreme Male Brain theory explaining autism, the continuum of cognitive capabilities extends between the natural faculties of empathizing and systemizing in the human brain. ${ }^{18}$ In neuroscience studies, the term anti-correlated networks of the brain has been coined to describe the phenomenon of alternating activation, in which mechanical tasks were able to deactivate the regions associated with social reasoning, and social tasks deactivated the regions associated with mechanical reasoning. ${ }^{19}$ The first mode of thinking is mechanistic and operates in a more bottom-up manner, being highly sensitive to the type of stimulus. However, the mentalizing system is more top-down, and is influenced by the cognitive context and much less by the surface characteristics of stimuli. ${ }^{20}$

The Imprinted Brain Theory describes the diametrical model of the social brain connecting the two cognition modes with mental illnesses. ${ }^{2}$ This model establishes a continuum of the intellectual capabilities of the social brain, extending from high mentalism in the psychotic spectrum to low mentalism in autistic spectrum conditions..$^{22}$ Accordingly, human talents can be divided into two large groups - these with excellent people skills and those with elevated mechanistic skills. Because of anti-correla-

16 Jonathan St. B. T. Evans, Thinking Twice: two minds in one brain (New York: Oxford University Press, 2010)

7 Jonathan St. B. T. Evans, Keith E. Stanovich, „Dual-Process Theories of Higher Cognition Advancing the Debate", Perspectives on Psychological Science, 8 (3) (2013), 223-241.

18 Simon Baron-Cohen, Autism and Asperger Syndrome. The Facts (Oxford: Oxford University Press, 2008), 62-75.

9 Jack, „A Scientific Case for Conceptual Dualism: The Problem of Consciousness and the Opposing Domains Hypothesis", 173-207.

20 Ibidem, 178

Psychosis and Autism as Diametrical Disorders of the Social Brain", 241-320.

22 Badcock, The Imprinted Brain: How Genes Set the Balance Between Autism and Psychosis. 
tion, both groups have deficiencies in the respective opposite domain. Autistic savantism is an example of elevated mechanistic and less than average mentalistic capabilities. The imprinted brain theory suggests that a reversed pattern of elevated mentalistic talent with reduced mechanistic abilities is found in psychotic savantism, a previously unsuspected condition. ${ }^{23}$

The mentalistic kind of knowledge tends to be ideological, contextual, holistic, top-down, centrally coherent and globally connected. Mechanistic thinking is wired to find insights and patterns on the local level, and tends to be non-contextual, reductionist, bottom-up, and noncentrally coherent. Numerous clinical studies have shown an increased local processing style in autistic spectrum conditions, whereas the psychotic spectrum exhibits an increased global processing bias. ${ }^{24}$ The global style has an advantage in social tasks and the local processing bias in mechanistic tasks. A genius is someone who has elevated levels of talent in both modes of thinking.

\section{CV:}

Dr. Amar Annus (b. 1974) is an is an Estonian scholar of Ancient Near Eastern literature, knowledge and religion. He has published numerous books and scholarly papers in English and Estonian. He has worked in the universities of Helsinki, Chicago and Berlin, currently he is associate professor of Near Eastern religious history at the University of Tartu, Estonia. More recently he has begun to use the methods of evolutionary psychology and cognitive sciences in his research in order to approximate population groups in ancient societies.

23 See: Badcock, „The Symmetry of Savantism“.

24 Crespi, Badcock, „Psychosis and Autism as Diametrical Disorders of the Social Brain“, 248. 